\title{
Impact of Information on Positive Nurturing of Adolescences Toward Better Career Choice: Study of Ikorodu Local Government Ikorodu Lagos, Nigeria
}

\author{
${ }^{1}$ Abimbola I. Alao \& ${ }^{2 M u t i a t ~ T . ~ J a m e s ~}$ \\ Office Technology and Management Department \\ Department of Business Administration \\ Lagos State Polytechnic, Ikorodu, Lagos, Nigeria \\ E-mails: abimbolaala020047@gmail.com; jamesmutiat@yahoo.com \\ Phones: +234803353370; +2348056118346
}

\begin{abstract}
Information now plays vital role in all aspect of human endeavor. As it is rightly said information is "power" if not informed, then one would be "deformed" The role of information in formation and nurturing adolescents cannot be overemphasis, as these adolescents will definitely grow to become adults of tomorrow. Types of information students are exposed to will have something to say about the type of adults they grown to become. Environmental factors which comprises but not limited to Home, Schools, and Religious Body have a significant role to play in nurturing adolescents in our society, especially now that information had been littered from various sources. Right source for information is germane to make these adolescents grow to responsible adults hence this study. The study is aimed at investigating the extent to which information has on positive nurturing of Adolescents in Lagos State Metropolis. Questionnaire was used as the major instruments of data collection. Five (5) Schools were selected at random across all the local government in Lagos State, (20) students from classes of SSI, SSII and SSIII, totaling sixty (60) students from each school leaving us with 300 students for the study population. Survey design mainly quantitative was used. The cumulative reliability coefficient of the instrument used was 0.87 . Data were analyzed using descriptive statistics, regression and correlation which was facilitated by using the (SPSS). Findings from the study reveals that, many homes are now failing in their responsibility of nurturing adolescents due to busy schedules of parents and other social activities. Schools and religious body now play active roles in giving the information they needed to nurture the adolescence, to become a responsible adult in our society. The study discussed recommendation based on the findings of the study.
\end{abstract}

Keywords: Information, Positive Nurturing, Students, Adolescents, National Development

Proceedings Reference Format

Abimbola, I.Alao \& Mutiat T. James (2021): Impact of Information on Positive Nurturing of Adolescences Toward Better Career Choice: Study of Ikorodu Local Government. Ikorodu Lagos, Nigeria. Proceedings of the 27th iSTEAMS Multidisciplinary Innovations \& Technology Transfer (MINTT) Conference. Academic City University College, Accra, Ghana. June, 2021. Pp 293-306 www.isteams.net/ghana2021. DOI https://doi.org/ 10.22624/AIMS/iSTEAMS-2021/N27P23

\section{INTRODUCTION}

Secondary School students which are mostly adolescent, are most times without any direction, whereby creating problems which directly or indirectly affect their future. (Amoah 2015, Rowland, 2004,). These students source information from various sources like the media, internet, peer groups, e.t.c in the society without 


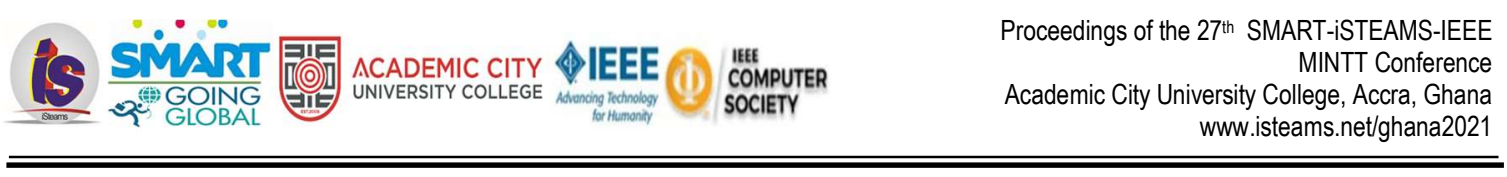

identifying different between good and bad ones. (Maluwa-Banda, 1998:294). Salami (2006) as cited by Shumba and Naong (2012) also found that factors such as the family of the student, school and age group affect up bring of adolescence. That is to say the family you came from either rich or poor, or families that are rich in information will definitely contributes to the good nurturing of the adolescence.

Adolescent or teenagers are one of major population of any given state or nation, they need to be adequately engaged for their future, failure to nurture them for a befitting future may lead to unhappiness and disapproval by society (Maluwa-Banda, 1998). One will begin to wonder why we have many depressed adolescents in recent time, lack of information or lack of access to the right information will definitely do more havoc to any given society.

\subsection{Review of Related Literature}

Dorr \& Lesser, 1980. Are of the opinion that children begin forming concepts about life at an early age, but since their knowledge is so fragmented, their concepts are stereotypical and narrow If no effort is made to contradict these narrow and stereotypical concepts, children maintain them into adolescence and young adulthood, when they proceed to make relatively uninformed in terms of the range of information and opportunities actually to them. Maliki and Uche (2007) emphasized that students' background factors such as socio-economic background of students, parental level of education, occupation, facilities at home, quality of residence, and family size are significant factors that can predict the effective accessibility of information resources among secondary school students. Another studies by Maliki and Uche (2007) have established that factors such as demographic variables, media resources' variables such as media resources' availability and accessibility as well as skills and competencies such as information, computer and digital literacy skills among others can influence students' utilization of media resources. Religious affiliation is the self-identified association of a person with a religion, denomination or sub-denominational religious group. The following supporting concepts are defined in Glossary and references: religion.

Religion is a school of thought including a set of beliefs, moralities, and rules that aim to guide humankind to happiness. Religion ensures the existence of life hereafter and defines the purpose of life. Spirituality is, however, a powerful inspirational force for searching the meaning of life, a deeper understanding of life values, appreciating the universe's magnitude; it is also a system of personal beliefs. Although spirituality and religion are considered as independent, especially in Western cultures. Religious affiliation plays a greater role in students nurturing, since most family respects their religion leader, they can give information on a career to young adult under their worship. There are some careers an individual belief may not take up; hence they will never encourage their adolescence toward such career In a recent study by Olukunle A. O. (2018), it was deduced that media resources have emerged as one of the most powerful vehicles for provision of access to unlimited information. This is an inseparable part of today's secondary school students. Students' now depend on media resources is increasing day-by-day and are also depending more on the invaluable educational resources for the learning activities

However, factors such as Environmental factors, like Homes, Schools, and Religious Group can influence students' nurturing ability if positive information are all accessible to these students. This is because these factors play direct role on the growth of the adolescence, Borchert (2002) explained that "environment may influence the growth of a child, for example, students who have lived on an island may choose a career dealing with the water. 


\subsection{Statement of the Problem}

Adolescence period is the time when children begins to be more realistic about life, during this period, students face significant barriers in accessing Information needed for their growth., these students find it difficult to locate all the information they needed for their formation, growth, and in most cases, they are not aware of where to get answers to questions about their future. The role of information in formation and nurturing adolescence cannot be overemphasis, as this adolescence will definitely grow to become adult of tomorrow. In recent times, emphases are not put on the information accessibility as important tool for nurturing adolescence in Nigeria, most Nigerian youth do not have access to good information regarding how they are being raised or nature, this is what led the society with wayward and irresponsible youth. Inability to have access to good information has been one of the main reasons we have many youths engaged in the fraudulent act like the Internet fraudsters (Yahoo! Yahoo), kidnappers, hoodlums and other social vices, etc.

Environment has also been failing in it responsibilities to this adolescence, most home which these adolescences came from are not up to their responsibilities, most parents don't have time to give their children or ward the information needed for their future betterment. Schools that should serve as guidance to the students also has failed in its responsibilities as almost all the school in our society now, don't have a professional as the guidance and counselors hence, these students are just without guidance and they tend to seek and access information from other available source like: peer groups, older friends, internet which are in most cases gave them wrong information regarding their future. As a results of the above stated problems, this study deems it fit to investigate the influence information accessibility from environmental factors such as, Home, school, and Religious affiliations has on the nurturing of Secondary School Students in Ikorodu Local Government, this study decided to take Ikorodu as the sample size because of the high population of Ikorodu.

\subsection{Research Questions}

The following are research questions formulated to guide the conduct of this study:

1. What impact does Information from homes has on the positive nurturing of adolescence in lkorodu Local Government toward their career choice?

2. What impact does Information from schools has on the positive nurturing of adolescence in Ikorodu Local Government toward their career choice?

3. What Impact does information from religious bodies has on positive nurturing of adolescence in Ikorodu Local Government toward their career choice?

\subsection{Research Design}

The research design adopted for the study is survey design mainly quantitative in nature. Questionnaire was used as the major instruments of data collection.

\subsection{Population}

The target population comprised Five (5) Schools from Ikorodu Local Government, these five schools were selected at random across Ikorodu Local Government. Twenty (20) students from classes of SSI, SS2 and SSIII, totaling sixty (60) students from each school leaving us with 300 students for the study population. A structured questionnaire was administered to these three hundred (300) students and all the questionnaires were completed and returned under close supervision of the Teachers and Rsearchers and Research Assistant which constituted the sample size for this research. 


\subsection{Research Instruments}

The instrument used in gathering the data in this research was a self-designed structured questionnaire the questionnaire was titled "Impact of Information on Positive Nurturing of Adolescences Toward the best career choice" constructed by the researchers. Section A was designed to collect demographic data from the respondents, Section B comprises of questions based on the Impact Information from; homes, Schools, and Religious body will have towards nurturing process of adolescents. Section $\mathrm{C}$ comprises of question based on all identifies factors discussed in the Literature review?

\subsection{Validation of the Research Instrument}

Before the study was carried out, the items on the questionnaire were tested to avoid ambiguity and to test for validity and reliability. All negatively worded items were reversely scored before data analysis. In an attempt to validates the instrument, experts in evaluation ascertained the face and construct validity. Ambiguous items were identified, and some items were restructured. Test-retest method of reliability was used to ascertain the constituency of the instrument within two weeks' intervals The cumulative reliability coefficient of the instrument used was 0.87 . Response rate was $100 \%$. Data were analyzed using descriptive statistics, regression and correlation which was facilitated by using the (SPSS).

\section{METHOD OF DATA ANALYSIS}

The collected data were entered into SPSS for statistical processing. The data collected were analyzed using descriptive statistics, regression, and correlation analysis. Descriptive statistics in form of percentages and mean were used to measure the constructs of the study. The use of graphs and charts were used to represent the deduction from the respondents.

\subsection{Analysis and Discussion}

\section{Distribution of Respondents by Class}

Table 1: Class

\begin{tabular}{lll}
\hline Option & Frequency & Percent \\
\hline SSS I & 100 & 33.3 \\
SSS II & 100 & 33.3 \\
SSS III & 100 & 33.3 \\
Total & 300 & 100.0 \\
\hline
\end{tabular}

Above table, presents the class of respondents, showing that selection equality was observed with $60(20 \%)$ each in SSS1 to SSS3 of all the selected schools. 


\section{Respondents Class Distribution}

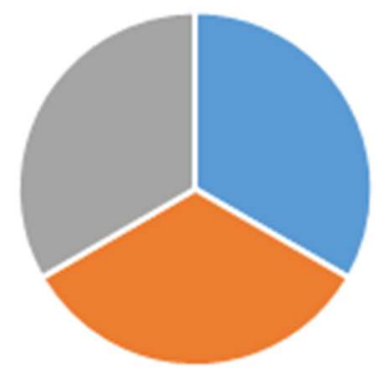

" SSSI | SSSII = SSSIII

Fig 1: Respondents Class Distributon

Table 2: Distribution of the Respondents by Class Specialization

\begin{tabular}{lll}
\hline & Frequency & Percent \\
\hline Science & 121 & 40.3 \\
Art & 98 & 32.7 \\
Commercial & 81 & 27.0 \\
Total & 300 & 100.0 \\
\hline
\end{tabular}

\section{Distribution of the Respondents by Class Specialization}

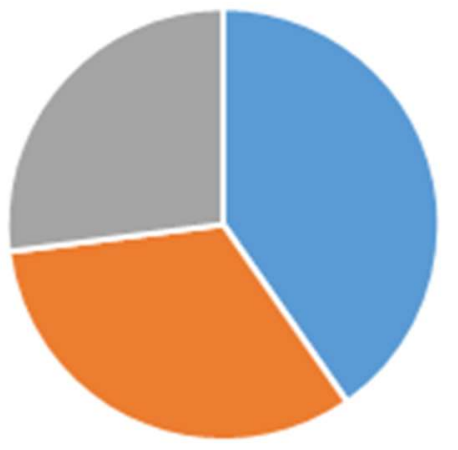

- Science $=$ Art $=$ Commercial

Fig 2: Distribution of the Respondents by Class Specialization 
Table 3: Religion Distribution of the Respondent

\begin{tabular}{lll}
\hline & Frequency & Percent \\
\hline Christianity & 183 & $61.0 \%$ \\
Islam & 117 & $39.0 \%$ \\
Total & $\mathbf{3 0 0}$ & $\mathbf{1 0 0 . 0}$ \\
\hline
\end{tabular}

Result from this table shows that 183 of the respondents are Christians, while 117 are Muslims. Obviously, most $(61 \%)$ of the respondents appear to be Christians.

\section{Religion Distribution of the Respondent}

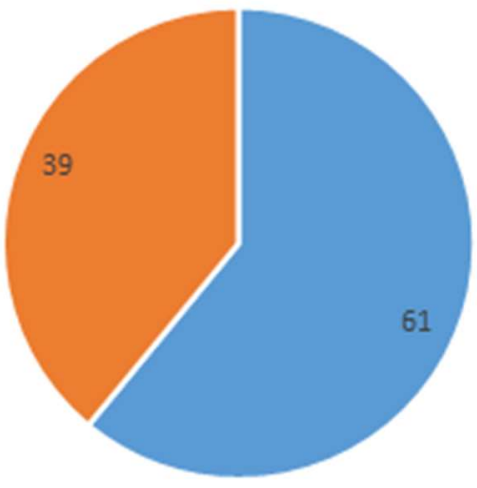

" Christianity = Islam

Fig 3: Distribution of the Respondents by Religion 
Answering Research Question1: Impact Information from school has on the positive nurturing of Adolescence in lkorodu Local Government toward their career choice?

Table 4: Impact of Information from School

\begin{tabular}{|c|c|c|c|c|c|}
\hline Options & $\begin{array}{l}\text { SA } \\
(\%)\end{array}$ & $\begin{array}{l}\text { A } \\
(\%)\end{array}$ & $\begin{array}{l}\text { D } \\
(\%)\end{array}$ & $\begin{array}{l}\text { SD } \\
(\%)\end{array}$ & Total \\
\hline $\begin{array}{l}\text { My school is capable in giving me information to nurture } \\
\text { me for future }\end{array}$ & $\begin{array}{l}61 \\
(20.3) \\
\end{array}$ & $\begin{array}{l}60 \\
(20)\end{array}$ & $\begin{array}{l}119 \\
(39.7)\end{array}$ & $\begin{array}{l}60 \\
(20)\end{array}$ & $\begin{array}{l}300 \\
(100) \\
\end{array}$ \\
\hline $\begin{array}{l}\text { Method of teaching and extra curriculum in my school } \\
\text { shows my abilities and help me to know what am best } \\
\text { in }\end{array}$ & $\begin{array}{l}98 \\
(32.7)\end{array}$ & $\begin{array}{l}102 \\
(34)\end{array}$ & $\begin{array}{l}100 \\
(33.3)\end{array}$ & $\begin{array}{l}0 \\
(0)\end{array}$ & $\begin{array}{l}300 \\
(100)\end{array}$ \\
\hline $\begin{array}{l}\text { My school gives me the information I needed for my } \\
\text { future }\end{array}$ & $\begin{array}{l}128 \\
(42.7)\end{array}$ & $\begin{array}{l}172 \\
(57.3)\end{array}$ & $\begin{array}{l}0 \\
(0)\end{array}$ & $\begin{array}{l}0 \\
(0)\end{array}$ & $\begin{array}{l}300 \\
(100)\end{array}$ \\
\hline $\begin{array}{l}\text { My performance in school shows my abilities and help } \\
\text { me know what I can do better }\end{array}$ & $\begin{array}{l}143 \\
(47.7)\end{array}$ & $\begin{array}{l}153 \\
(51)\end{array}$ & $\begin{array}{l}4 \\
(1.3)\end{array}$ & $\begin{array}{l}0 \\
(0)\end{array}$ & $\begin{array}{l}300 \\
(100)\end{array}$ \\
\hline My school has guidance and counselor(s) & $\begin{array}{l}123 \\
(41)\end{array}$ & $\begin{array}{l}151 \\
(50.3)\end{array}$ & $\begin{array}{l}21 \\
(7)\end{array}$ & $\begin{array}{l}5 \\
(1.7)\end{array}$ & $\begin{array}{l}300 \\
(100)\end{array}$ \\
\hline $\begin{array}{l}\text { My school guidance and counselors have knowledge } \\
\text { and experience to advice student on career issues }\end{array}$ & $\begin{array}{l}122 \\
(40.7)\end{array}$ & $\begin{array}{l}145 \\
(48.3)\end{array}$ & $\begin{array}{l}25 \\
(8.3)\end{array}$ & $\begin{array}{l}8 \\
(2.7)\end{array}$ & $\begin{array}{l}300 \\
(100)\end{array}$ \\
\hline $\begin{array}{l}\text { Answering Research Question 2: Impact Information } \\
\text { from home has on the positive nurturing of adolescence } \\
\text { in Ikorodu Local Government toward their career } \\
\text { choice? }\end{array}$ & & & & & \\
\hline
\end{tabular}

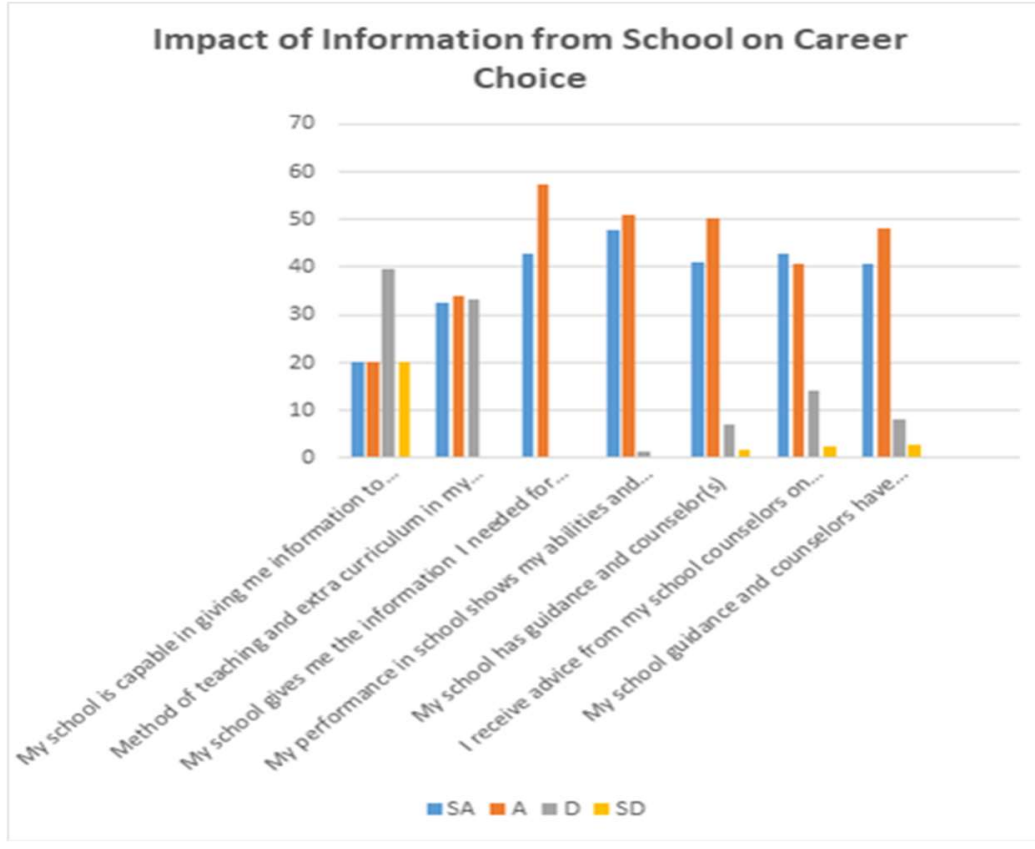

Fig 4: Impact of information from School on Career 


\begin{tabular}{|l|l|l|l|l|l|}
\hline Options & $\begin{array}{l}\text { SA } \\
(\%)\end{array}$ & $\begin{array}{l}\text { A } \\
(\%)\end{array}$ & $\begin{array}{l}\text { D } \\
(\%)\end{array}$ & $\begin{array}{l}\text { SD } \\
(\%)\end{array}$ & \begin{tabular}{l} 
Total \\
\hline
\end{tabular} \\
\hline My parents are accessible to give me information about my future & $\begin{array}{l}97 \\
(32.3)\end{array}$ & $\begin{array}{l}148 \\
(18.3)\end{array}$ & $\begin{array}{l}55 \\
(49.3)\end{array}$ & $\begin{array}{l}0 \\
(0)\end{array}$ & $\begin{array}{l}300 \\
(100)\end{array}$ \\
\hline My siblings advise me on my choice of career and other things & $\begin{array}{l}142 \\
(47.3)\end{array}$ & $\begin{array}{l}46 \\
(15.3)\end{array}$ & $\begin{array}{l}112 \\
(37.3)\end{array}$ & $\begin{array}{l}0 \\
(0)\end{array}$ & $\begin{array}{l}300 \\
(100)\end{array}$ \\
\hline My parents are always available for any information in needed from them & $\begin{array}{l}119 \\
(39.7)\end{array}$ & $\begin{array}{l}129 \\
(43)\end{array}$ & $\begin{array}{l}52 \\
(37\end{array}$ & $\begin{array}{l}0 \\
(0)\end{array}$ & $\begin{array}{l}300 \\
(100)\end{array}$ \\
\hline
\end{tabular}

\section{Impact of Information from home on career choice}

60

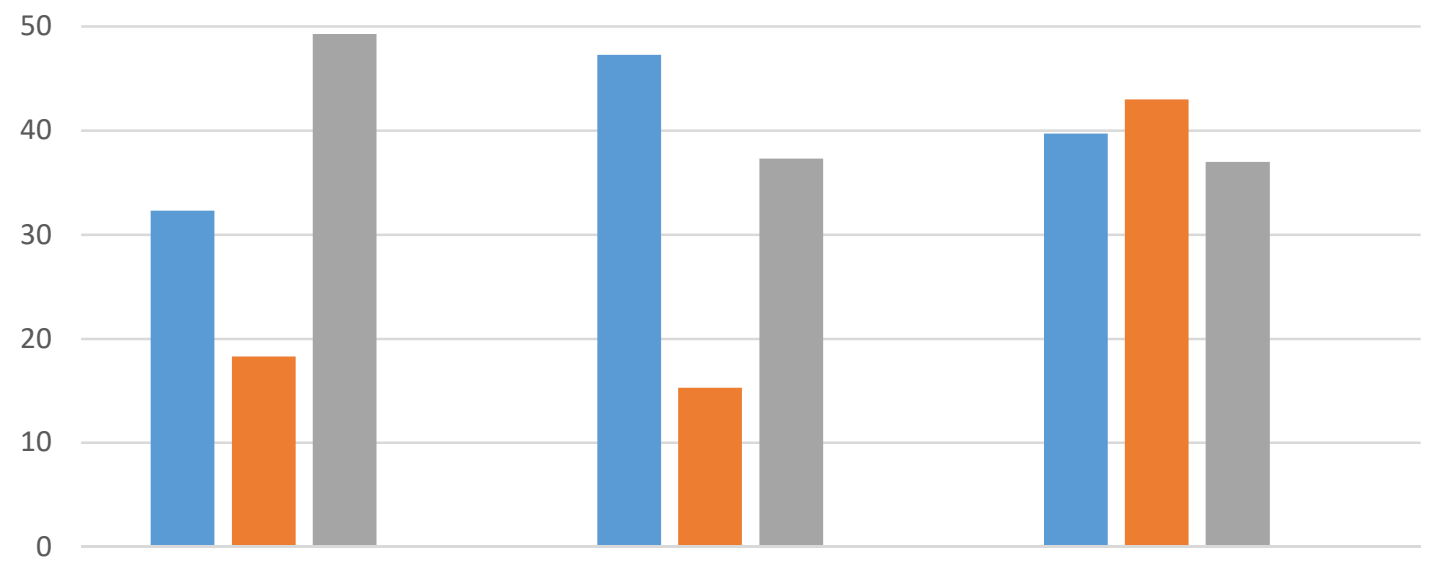

My parents are accessible to give My siblings advise me on my My parents are always available me information about my future choice of career and other things for any information in needed

$\square \mathrm{SA} \backsim \mathrm{A} \square \mathrm{D} \backsim \mathrm{SD}$

Fig 4: Impact of information from School on Career 
Answering Research Question 3: Impact information from religious bodies has on positive nurturing of adolescence in lkorodu Local Government toward their career choice?

\begin{tabular}{|c|c|c|c|c|c|}
\hline I receive information for my future career my religious leader chooses for me & $\begin{array}{l}118 \\
(39 . \\
3)\end{array}$ & $\begin{array}{l}113 \\
(37 . \\
7)\end{array}$ & $\begin{array}{l}69 \\
(23)\end{array}$ & $\begin{array}{l}0 \\
(0)\end{array}$ & $\begin{array}{l}300 \\
(10 \\
0)\end{array}$ \\
\hline $\begin{array}{l}\text { Information from my spiritual leaders help me in so many things including my } \\
\text { development in life }\end{array}$ & $\begin{array}{l}168 \\
(56)\end{array}$ & $\begin{array}{l}97 \\
(32 . \\
3)\end{array}$ & $\begin{array}{l}315 \\
(11 . \\
7)\end{array}$ & $\begin{array}{l}0 \\
(0)\end{array}$ & $\begin{array}{l}300 \\
(10 \\
0)\end{array}$ \\
\hline $\begin{array}{l}\text { Our leaders encourage and organize career talk for the essential information } \\
\text { required to choose a career }\end{array}$ & $\begin{array}{l}123 \\
(41)\end{array}$ & $\begin{array}{l}139 \\
(46 . \\
3)\end{array}$ & $\begin{array}{l}38 \\
(12 . \\
7)\end{array}$ & $\begin{array}{l}0 \\
(0)\end{array}$ & $\begin{array}{l}300 \\
(10 \\
0)\end{array}$ \\
\hline My religious leader has a positive impact in the choice of my career & $\begin{array}{l}176 \\
(58 . \\
7)\end{array}$ & $\begin{array}{l}100 \\
(33 . \\
3)\end{array}$ & $\begin{array}{l}24 \\
(8)\end{array}$ & $\begin{array}{l}0 \\
(0)\end{array}$ & $\begin{array}{l}300 \\
(10 \\
0)\end{array}$ \\
\hline $\begin{array}{l}\text { My religious body gives me the information I needed for my development as a } \\
\text { student }\end{array}$ & $\begin{array}{l}112 \\
(37 . \\
3)\end{array}$ & $\begin{array}{l}109 \\
(36 . \\
3)\end{array}$ & $\begin{array}{l}65 \\
(21 . \\
7)\end{array}$ & $\begin{array}{l}14 \\
(4 . \\
7)\end{array}$ & $\begin{array}{l}300 \\
(10 \\
0)\end{array}$ \\
\hline
\end{tabular}

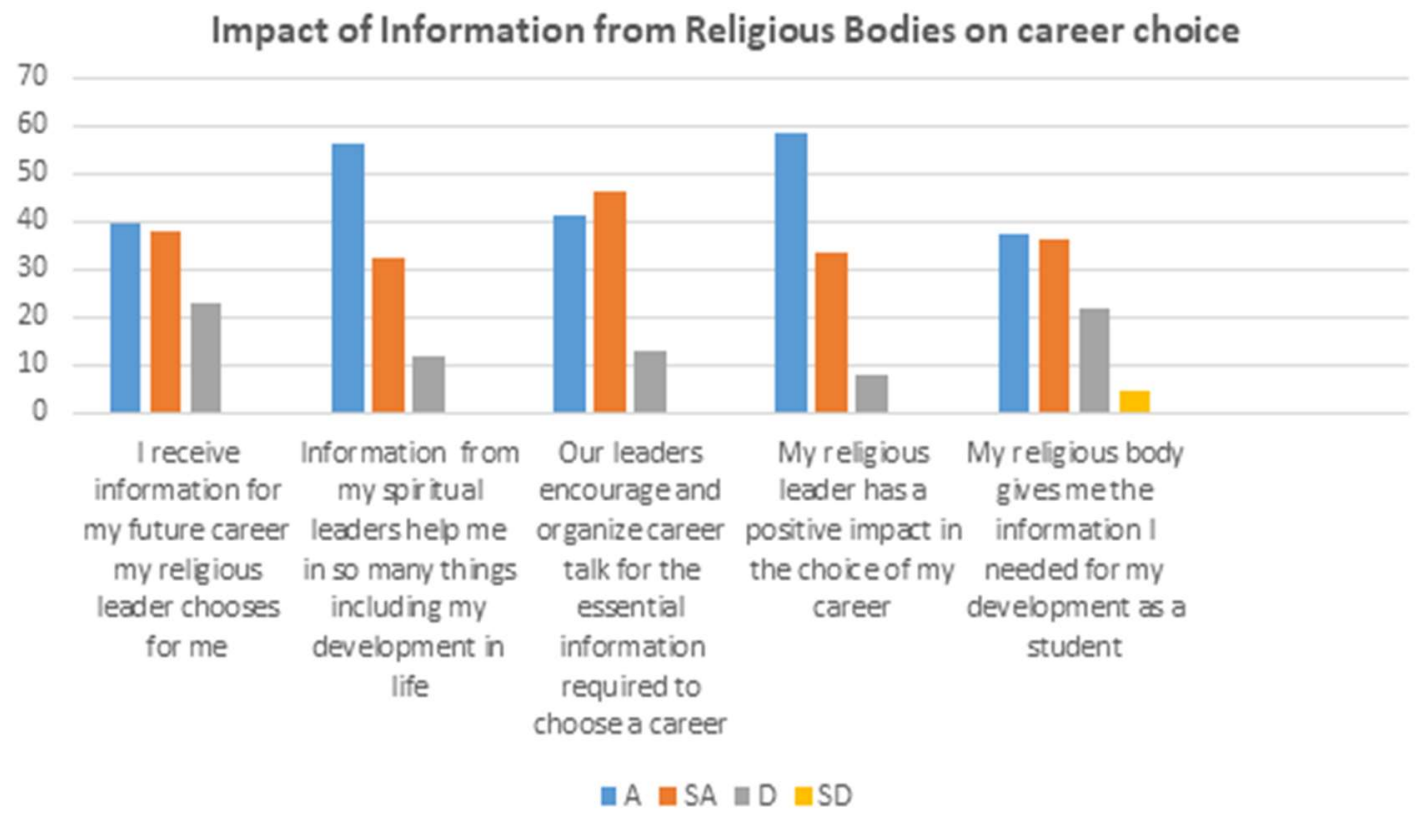

Fig 5: Impact of information from School on Career 


\begin{tabular}{|l|l|l|l|l|l|}
\hline- & 158 & 115 & 19 & 8 & 300 \\
$\begin{array}{l}\text { Others Sources } \\
\text { I have confidence in the Information I got from media }\end{array}$ & $(52.7)$ & $(38.3)$ & $(6.3)$ & $(2.7)$ & $(100)$ \\
\hline & 86 & 63 & 112 & 39 & 300 \\
I have confidence in the Information I got from, internet & $(28.7)$ & $(21)$ & $(37.3)$ & $(13)$ & $(100)$ \\
\hline & 174 & 102 & 24 & 0 & 300 \\
I have confidence in the Information I got peer groups & $(58)$ & $(34)$ & $(8)$ & $(0)$ & \\
\hline & 135 & 127 & 38 & 0 & 300 \\
My role model gives me the information I needed for my nurturing & $(45)$ & $(42.3)$ & $(12.7)$ & $(0)$ & $(100)$ \\
\hline & & & & & \\
\hline
\end{tabular}

\section{Information from other sources}

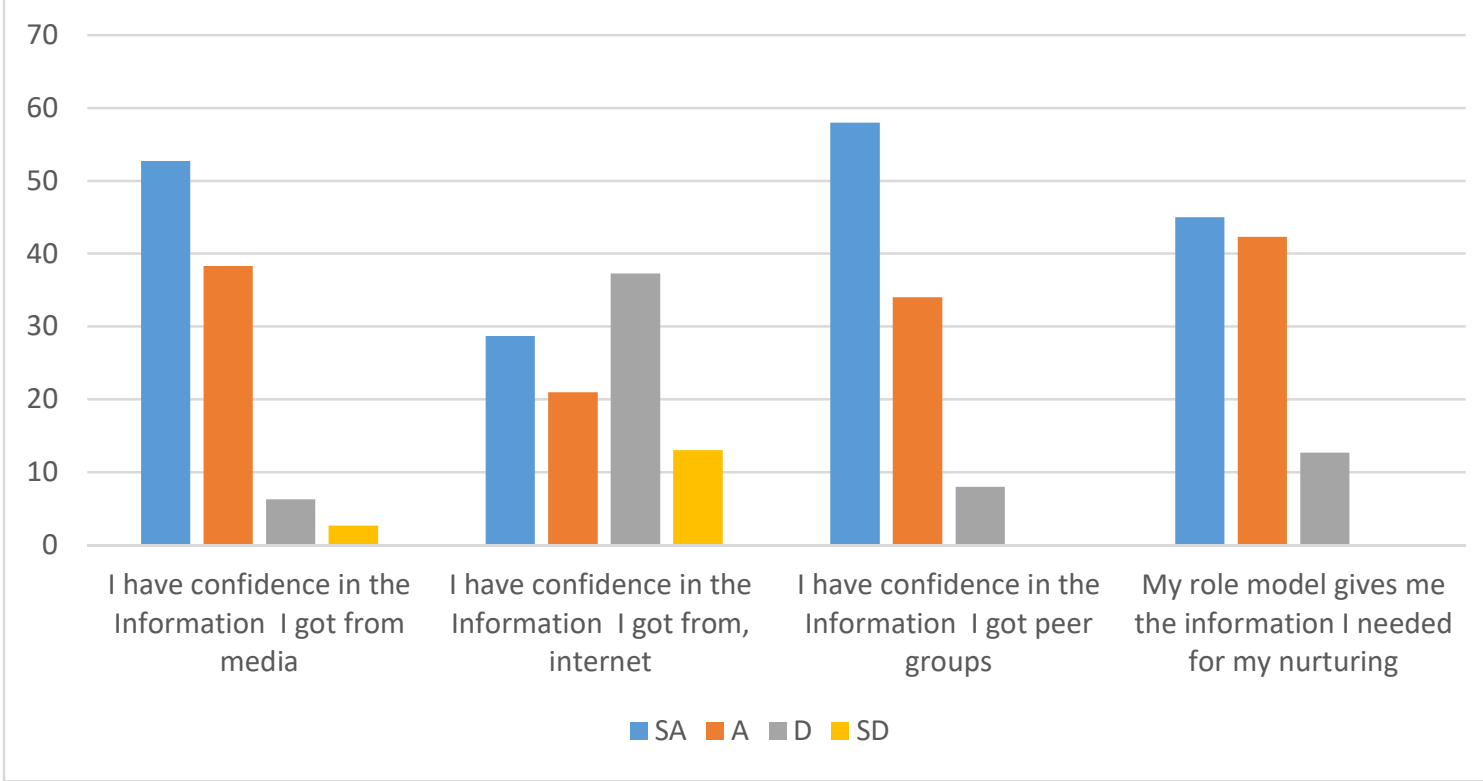

Regression analysis on Impact of Information from Homes to Students in Ikorodu Local Government

\begin{tabular}{|l|l|l|l|l|}
\hline Parameter & Co-efficient & $\begin{array}{l}\text { Standard } \\
\text { Coefficients }\end{array}$ & T-Cal & Probability \\
\hline Constant & 0.072 & 0.053 & 1.358 & 0.175 \\
\hline Impact of Information & 0.007 & 0.009 & 0.144 & 0.886 \\
\hline
\end{tabular}

In the table above, Home has a positive but insignificant relationship with Information Accessibility, having a coefficient and $p$-value of $0.072(0.175)$ respectively. Therefore, home does not have a -significant impact on Information of adolescence in lkorodu Local Government according to this study. 
Regression analysis of impact of schools in giving information to students to guide then for their future

\begin{tabular}{|l|l|l|l|l|}
\hline Parameter & Co-efficient & $\begin{array}{l}\text { Standard } \\
\text { Coefficients }\end{array}$ & T-Cal & Probability \\
\hline Constant & 0.203 & 0.051 & 0.199 & 0.000 \\
\hline Information & -0.119 & 0.009 & -0.117 & 0.276 \\
\hline
\end{tabular}

From the table above, it was deduced, with coefficient and p-value of $0.203(0.000)$,

This have a level of significance to be at $1 \%$, indicating that a unit increase in their coefficients results to the coefficient of Information Accessibility. Therefore, schools play a significance role in the giving information to adolescence in Ikorodu Local Government.

Regression Analysis of impact of the Religious Body/ Affiliation in giving information to Adolescence on career choice

\begin{tabular}{|l|l|l|l|l|}
\hline Parameter & Co-efficient & $\begin{array}{l}\text { Standard } \\
\text { Coefficients }\end{array}$ & T-Cal & Probability \\
\hline Constant & 0.123 & 0.137 & 1.988 & 0.048 \\
\hline Information & -0.020 & 0.034 & -0.598 & 0.576 \\
\hline
\end{tabular}

Religious affiliation exhibits a positively significant relationship with respondents with coefficient and $p$-value of $0.123(0.048)$ at $5 \%$ religious affiliations according to this study play a significant role in giving information to adolescence in Ikorodu Local Government.

\section{DISCUSSION OF THE FINDINGS}

Findings from this study showed that there was positive impact of home on the students under study, but not a significant influence in the information on the students nurturing process. This means, that the students recognize their home but does not rely on the homes for the homes for nurturing and up-bring from the study, it was deduced that the type of information students got from home are not useful for them for their growth and nurturing. This finding is in contrary to the view A.N . Okeke (2000) whose investigation revealed that parental pressure affects children growth. this finding supports the view of T. Lawer Dede (2015) that says, family, society, peer group and even event in the school have great influence on development of students. Another study by Tella 2003, opinioned that Parents play a significant role in laying good foundation for their children.

The result of the findings also showed that schools play a significance role in giving information to students, schools tend to exhibits a positively significant relationship with Information programs like school career days, availability of school councilors was cited as having a positive impact on students' nurturing process. this means that students are freer in school than in their various homes regarding the information they gather for their growth. Religious Affiliation according to the study, play a significance role in giving information needed for adolescence nurturing and development. This finding can be so because most of students have been attending the religious center right from their toddler, as they tend to get use more to religious settings even more than their homes. This assertion can be backed-up by J. Nyamwange opinion that Religion is a school of thought including a set of beliefs, moralities, and rules that aim to guide humankind to happiness. 


\section{CONCLUSION}

This study was conducted with a view of establishing relation between the independent variable and dependent variable This study provided empirical data on Information from home, schools and religious bodies among secondary school students in Ikorodu Local government, Lagos State Nigeria. it was also concluded according to the findings that 'home' which supposed to play a pivotal role in students' upbringing and nurturing has being carried away with other materials things, hence, failing in its responsibilities, This is some of the reasons we have many depressed teenagers, committing suicides this days, joining evil vices from the internet, engaging in kidnapping and so on.

It was reveals that students now access information needed for their growth from other sources like School, Religious body, media, internet, peer group e.t.c. Religious bodies now take the responsibilities of parents at home because adolescents are exposed to this environment from toddler and they feel more comfortable discussing their future ambitions to their "religious parents" according to the findings from the study.

\section{RECOMMENDATION:}

Based on the findings of this research work, the following recommendations are made:

1. Home should be up and doing to their responsibilities, many adolescences are now going astray, while parents are busy looking for other materials facilities for the growth of the children at the expenses of these adolescence. Parents are not even aware of what is going on with their children. Parents should adopt what is known as family time with their children to get to know their children better and give them the needed information to their formation and nurturing for them to become good citizen and responsible adults.

2. Schools should continue to play their parental roles on the nurturing of these adolescences, moreover, they the professionals in that area, the availability of school guidance and councilor is paramount to enable these students get the needed information for their nurturing. Schools have a lot to do since most parent relays on them for their children nurturing, career day and other interesting activities should be introduced to prepare these adolescences for their future.

3. Religious leaders as one the most respected institutions among human also need to be up and doing in nurturing the adolescence. Emphasis should be made on the children and youth groups in their midst, this is important so that the nurturing will be guided and watched over and prayed for from time to time.

4. Government also need to have hand in this, in other to have a sustainable development in our society. The Federal, State and Local government should empower their Ministries of Youth Affairs in other to engage the youths and students in a meaningful and productive activities to curtail their exposure into evil vices that might likely ruined their life.

5. Students and adolescence need to be up and doing, they should guide against any forms of youthful exorbitant that might ruin their lives. They should seek for meaning information for their future, engage in other productive things aside from the education to make them busy and tactful, so that the will be devil workshop because the idled hands are not only the devils workshop but the devil himself. 


\section{REFERENCE}

1. Sarwar and A. Azmat (2018): Factors Having Impact on the Career Decisions: Study of Business Graduates in Pakistan, Business Management Dynamics Vol.2, No.7,.

2. A.J. Head,: Learning Curve (2015): How College Graduates Solve Information Problems Once They Join the Workplace. SSRN. Pp. 54-60

3. Amoah (2016): Social career influence of Xhosa adolescents elicited using the systems theoryframework in a peri-urban South African Township. South African Journal of Higher Education, 30(3), 111-137

4. Borchert (2015): Students' Educational and Occupational Aspirations Predicted by Parents and Adolescents Characteristics. European Journal of Social Sciences and Education

5. C.S Bruce., M.M Sormerville (2017): Diversifying Information Literacy Research: An Informed Learning Perspective. Vol.19 No.2 pp.19-33

6. A.Gandhe (2017): Redefining Information Literacy in Indian Context, Scholarly Research Journal for Interdisciplinary Studies, ISSN 2278-8808, VOL- 4/36.

7. Dorr \& Lesser, (2016): Social career influence of Xhosa adolescents elicited using the systems theory framework in a peri-urban South African Township. South African Journal of Higher Education, 30(3), 111-137.

8. G Walton \& M Hepworth (2014): Developing People's Information Capacity: Fustering Information Literacy in Educational workplace and Community. London U.k. Emerald Group Publishing Limited. pp.78 .

9. L. A Berger,.., \& D. R Berger (2015): The talent management handbook Beijing: China Economic Publishing House. p.151.

10. L.O.Aina: . Library and Information Science (2004): Text for Africa. Third World Information Services: Ibadan, pp.53

11. L. P. Mileder,, A. Schmidt,., \& H. P Dimai, (2014.): Clinicians should be aware of their responsibilities as role models: A case report on the impact of poor role modeling. Medical Education Online, pp. 19, $1-4 .$.

12. Rowland, 2004: Redefining Information Literacy Context, Scholarly Research Journal for Interdisciplinary Studies, ISSN 2278-8808, VOL- 4/36

13. Maliki and Uche (2013): Faculty and student perceptions and behaviours related to information literacy: A pilot study using triangulation. Journal of Information Literacy, 7(2), 80-96.

14. Maluwa-Banda, (2004): ,. Youth as People: The Protective Aspects of Youth Development in After School. Annals of the American Academy of Political and Social Science, 591, pp. 55-71.

15. M. Tom and Erik Brynjolfsson (2017) "Track How Technology is Transforming Work," Nature, vol. 544, No. 7650 ,

16. N. Weiler,(2017):. Reality and career planning. Reading, MA: Addison-Wesley Publishing Company, Inc.

17. Okobiah, O.C., and Okorodudu, R.I. ( 2004): Issues, Concepts, Theories and Technologies of Guidance and Counseling, Benin City. Ethiope Publishing. Delta.

18. Olukunle A. O. (2018): Influence of Peer Group Relationship on the Academic Performance of Students in Secondary Schools (A Case Study of Selected Secondary Schools in Atiba Local Government Area of Oyo State). Global Journal of HUMAN-SOCIAL SCIENCE: A Arts \& Humanities - Psychology Volume 16 Issue 4 Version 1.02016. 
19. Salami (2006): Faculty and student perceptions and behaviours related to information literacy: A pilot study using triangulation. Journal of Information Literacy, 7(2), 80-96.

20. Shumba and Naong (2012): A Study on Factors Influencing today's Youth Career Choice. International Journal of Physical and Social Science 5 (1), 496-511

21. S. Bury(2016): Learning from faculty voices on information literacy. Reference Services Review, 44(3), 237-252.

22. S. Kerka (2002): Will we all be portfolio workers? ERIC/ACVE Publication.,

23. T. Redman, \& A. Wilkinson (2001).: Contemporary Human Resources Management, NewYork: Financial Times Prentice Hall. 2001

24. W. C Briddick, , H Sensoy-Briddick,, \& S. Savickas,. : Career construction materials: The story of a career development curriculum in a Turkish school. Early Child Development and Care, pp.1-12, 